\title{
International Accounting in a Trilateral MBA Program
}

\author{
Harold T. Little Jr. (Corresponding author) \\ Department of Accounting, Western Kentucky University \\ 1906 College Heights Blvd., \#11061, Bowling Green, KY, 42101-1061, USA \\ Tel: 270-745-6978Ｅ-mail: harold.little@wku.edu \\ Minwoo Lee \\ Department of Accounting, Western Kentucky University \\ 1906 College Heights Blvd., \#11061, Bowling Green, KY, 42101-1061, USA \\ Tel: 270-745-5001Ｅ-mail: minwoo.lee@wku.edu
}

\author{
Mark T. Ross \\ Department of Accounting, Western Kentucky University, USA \\ Tel: 270-745-2964_Ｅ-mail: mark.ross@wku.edu
}

Received: May 07, 2012 Accepted: May 19, 2012 DOI: 10.5296/ijafr.v2i1.1951

\begin{abstract}
This paper describes the rationale used in the development, delivery, and subsequent evaluation of an international accounting course required of students in an MBA program. The primary purpose of the course was to provide students in a collaborative arrangement among three universities with an exposure to emerging international accounting and reporting issues, as well as an opportunity to enhance the decision-making skills necessary to be successful in a global business environment. Included in the paper is a discussion of the issues encountered when incorporating the course into the curriculum, an explanation of how the course was tailored to fit with the program's objectives, and a critique of the course from both the students' and instructor's perspective. Suggestions for design changes aimed at improving the course structure and content can provide valuable insight to both accounting educators and MBA program administrators as they consider the creation and subsequent implementation of an international accounting course.
\end{abstract}

Keywords: accounting education, decision making, faculty training, international accounting, international financial reporting standards, IFRS, MBA curriculum, U.S. GAAP 


\section{Introduction}

Major changes are coming to both the reporting of financial information, and the related accounting education, as a convergence of U.S. generally accepted accounting principles (GAAP) and international financial reporting standards (IFRS) is expected to be completed within the next few years (Bates, Waldrup, and Shea, 2010; SEC, 2011). An understanding of current international issues, especially those pertaining to international accounting policies and financial reporting standards, is critical to the success of business students (Ashcroft, Chevis, and Smith, 2008). Given that non-accounting majors often encounter accounting standards only in their introductory accounting courses, focusing on international financial reporting standards at the intermediate or advance accounting levels limits the exposure of future users of accounting information primarily to those students who are accounting majors.

Starting in 2000, the Securities and Exchange Commission (SEC)began to solicit comments from preparers and users of financial information provided in publicly issued financial statements. Practicing accountants, academicians, financial analysts, and legal professionals weighed in on the concept of adopting a principles-based concept of financial reporting. The consensus of the group was that changes to international accounting policies will be made, so preparing for them is an important and inevitable concern.

IFRS is an attempt by the International Accounting Standards Board (IASB) to create a single set of high quality, uniform, global accounting standards. European Union (EU) countries started implementing the new international accounting standards in 2005, requiring the use of IFRS for those countries wishing to belong. In the years since, Australia, Canada, China, India, Israel, Japan, Korea, and Mexico have followed suit by adopting IFRS in whole or by significantly converging their own generally accepted accounting standards with IFRS. Already adopted by over 100 countries, IFRS is quickly becoming the global accounting standard for recognizing, recording, and reporting economic events. For example, companies wishing to trade on international and national stock exchanges in Europe are required to use IFRS.

\section{U.S. GAAP and IFRS}

For several years, the Financial Accounting Standards Board (FASB) and IASB have sought convergence of U.S. GAAP and IFRS. On several occasions, the two organizations have publicly reported their commitment to work together to minimize and, if possible, eliminate differences between U.S. GAAP's rules-based and IFRS's principles-based standards. Although progress is being made, there remains a significant amount of work to be completed before the U.S. is ready to require the adoption of IFRS as its primary basis of reporting financial information for large public multinational enterprises.

In 2008, the SEC issued a proposed road map to a single set of high quality accounting standards. The SEC's action provided evidence of its support for moving toward a common standard to account and report on a global basis. In February 2010, the SEC took another step by issuing a report, which expressed the SEC's continued support of the "coming together" of U.S. GAAP and IFRS. The report went further than the 2008 report in that it proposed an adoption date between 2014 and 2015.By publishing a work plan (Commission 
Statement in Support of Convergence and Global Accounting Standards, SEC Release Nos. 33-9109, 34-61578), the SEC expressed its belief that a single set of high-quality globally accepted accounting standards would benefit U.S. investors and other users of financial information published by multinational organizations.

Section VI (Human Capital Readiness) of the SEC's 2010 report also acknowledged the need for comprehensive training [in IFRS]. The SEC explicitly stated that colleges and universities would need to include IFRS in their curricula in order to facilitate the training of future U.S. trained preparers and users of financial statements for U.S. publicly traded companies.

\section{IFRS and today's MBA student}

Graduates from MBA programs, that desire upward mobility, should be able to make high-level business decisions based on an understanding of complex financial information. Forms in which this information comes are annual reports, analyst evaluations, SEC filings (e.g., 10-K's and 10-Q's), and other publicly available documents. As potential employees of multinational organizations, MBA students are expected to have the ability and knowledge to analyze financial information prepared using internationally acceptable accounting policies. If MBA students are to be competitive in today's global business environment, they need a graduate education that will expose them to the sophisticated financial, economic, and accounting concepts used to prepare the information from which they will make informed business decisions. This paper discusses the development, delivery, and evaluation of an international accounting course taken as part of the required curriculum of an MBA program with the unique characteristic of being a collaboration of universities located in three different countries (Canada, USA, and Mexico).

\section{Trilateral MBA program}

\subsection{Participating Universities}

Western Kentucky University, Universite de Moncton, and Universidad Autonoma de Queretaro participate in a joint (trilateral)MBA degree program, which requires students to study at all three universities. The program is designed for students who are seeking the diversity of a study abroad program coupled with earning an MBA degree that has an international business focus. Students take three semesters (11courses or 33 semester hours) of course work, all taught in English, followed by a semester-long internship in a company or governmental agency in one of the three countries visited while in the program.

\subsection{Trilateral MBA Program Description}

Students begin the program in the fall at the Universite de Moncton in Canada, where they take courses in international marketing, logistics and e-commerce, and organizational behavior. During the spring semester, courses in international accounting, international finance, and management information systems are taken at Western Kentucky University in the USA. Coursework for the summer semester, taken in Mexico at the Universidad Autonoma de Queretaro, includes international economics, international management, and strategic management. After their fall semester internship, students are awarded an AACSB 
internationally accredited MBA degree.

Students progress through the program as part of a cohort. Cohorts vary in size from six to nine students. Each cohort consists of students from each of the three participating universities. Students are responsible for their home-school's tuition, as well as all travel, housing, and miscellaneous expenses. Scholarships are usually available to cover a portion of the tuition. As part of the admission process, introductory coursework in accounting, economics, finance, information management, management, marketing, and statistics are required. Those students having a background in business are assumed to have met this requirement. Additionally, each student must have a minimum GMAT score of 450 and an overall undergraduate grade point average of 2.5 on a 4.0 scale or its equivalent. For those students where English is not their first language, a minimum TOEFL score of 550is required.

\subsection{Course title and description}

Western Kentucky University was responsible for developing a course that satisfied the international accounting requirement of the program. The formal title of the course was Special Topics in Business: International Accounting. [Note: The Special Topics
[Ne designation was assigned to the course as it was initially thought that the course would be offered only one time. At the time of this paper, the course has been offered three times and a title change is being considered.] As the current title suggests, the course exposed MBA students to international financial reporting and accounting standards. Anticipating that they will work in a global environment, the primary focus of the course was to allow the students to develop and improve their abilities to read, interpret, analyze, and understand publicly available financial information prepared using international accounting standards. International Accounting exposed graduate-level students to (1) financial statements prepared using emerging international financial reporting standards and U.S. GAAP; (2) principles-based policy choices used to recognized and report corporate financial data for multinational publicly traded companies; (3) examples of executive decisions that affected global business operations; (4) peer-reviewed academic international accounting research; and (5) articles prepared both by and for practitioners. The course served as an introduction to international accounting and reporting issues for graduate-level students, regardless of whether their undergraduate major was in accounting or not.

\subsection{Course development issues}

Rationale for developing the course was two-fold: (1) to meet Western Kentucky University's obligation to offer an international accounting course, (2) to introduce MBA students to concepts pertaining to international accounting standards. The formal obligation to offer the course was agreed upon by Western Kentucky University in order to participate in the Trilateral MBA consortium. However, the manner in which students would be introduced to international accounting standards was left up to the professor assigned to create and develop the course.

In developing the course, several student-specific issues (e.g., course load, language limitations, oral and written communication limitations, once-a-week class sessions, prior (financial) accounting exposure, and expected participation in other international program 
activities and courses) had to be considered. The most critical issue was the level of prerequisite accounting knowledge possessed by the students, as covering international accounting topics deemed most important to future employers of MBAs was integral to both the perceived value of the course and the success of the overall MBA program.

To address the critical issue of a deficiency in prerequisite accounting knowledge, U.S. generally accepted accounting principles and international accounting principles were simultaneously studied. This method for refreshing students' financial accounting knowledge worked far better than scheduling an intensive review of financial accounting principles during the first few meetings of the course as was tried the first time the course was taught. A noticeable improvement in the quality of student questions, comprehension, participation, and enthusiasm were consequences of this change in pedagogy. It also permitted an increase in the number of topical coverage.

Exhibit 1 compares academics' and practitioners' (CFO's and managing partners of U.S. CPA firms) ranking of the most important international accounting topics.

Exhibit 1: Most Important International Accounting Topics as Ranked by Academics and Practitioners.

\begin{tabular}{|l|l|l|}
\hline$\underline{\text { Rank }}$ & $\underline{\text { Academics }}$ & $\underline{\text { Practitioners }}$ \\
\hline 1 & Foreign currency translation and risk & $\begin{array}{l}\text { Foreign currency translation and } \\
\text { risk }\end{array}$ \\
\hline 2 & $\begin{array}{l}\text { Environmental and cultural differences in } \\
\text { international accounting }\end{array}$ & $\begin{array}{l}\text { Consolidated statements of } \\
\text { multinational corporations }\end{array}$ \\
\hline 3 & $\begin{array}{l}\text { International transfer pricing } \\
\text { International portfolio risk and } \\
\text { financial services }\end{array}$ \\
\hline
\end{tabular}

Source: "What Are Students Taught in International Accounting Courses?," Bert J. Zarb, Philip Jagolinzer, The CPA Journal (2008), 78:9; Accounting \& Tax Periodicals, p. 60-65.

The latitude to create and develop the course permitted the professor to establish the direction in which the efforts of the professor and students would be directed. After working with the Trilateral MBA program administrator, it was decided that the goal of the course should be to prepare graduate-level students to become productive and engaged business leaders with an ability to read, interpret, analyze, and utilize complex international financial information to make informed business decisions in a global business environment. This financial information is frequently found in publicly available financial reports of multinational enterprises. 


\section{Mll Macrothink}

International Journal of Accounting and Financial Reporting

ISSN 2162-3082

2012, Vol. 2, No. 1

Through a variety of pedagogies, the students were exposed to an explanation of the impact of culture on the development of emerging financial reporting issues, international accounting standards, international financial reporting standards, and financial statements for multinational enterprises prepared using U.S. GAAP and IFRS. The following three pedagogical tools formed the foundation for the course: the textbook, peer-reviewed and practitioner research articles, and the students' own research project.

\subsection{Pedagogical tools used in the course}

International Accounting and Multinational Enterprises, $6^{\text {th }}$ edition by Radebaugh, Gray, and Black (2006) was the primary textbook for the course. The authors of the textbook targeted their book at the master's level student looking to broaden their horizons, as well as practicing accountants, managers, and consultants wanting to become more involved in the international aspects of accounting. The arrangement of the textbook's chapters took the student from broad issues (e.g., the evolution of international business and financial statement analysis) to specific accounting topics (e.g., financial statement transparency and disclosure, business combinations, and international budgeting and performance evaluation.)Articles from high quality peer-reviewed academic and practitioner journals provided an up-to-date and well-balanced understanding of specific topics. The reading list for the course is in Appendix A.

During the course, students were given the opportunity to compare financial statement titles and presentation formats suggested by U.S. GAAP and IFRS. For example, the IASB recommends using Statement of Financial Position instead of Balance Sheet; Statement of Comprehensive Income instead of Income Statement; and Statement of Shareholders' Equity instead of Statement of Stockholders' Equity. The Statement of Cash Flows retains its title under both U.S. GAAP and IFRS. Annual reports for Coca-Cola, General Motors, Ford Motor Company, Nestle, Nissan Motor, Sumitomo Corporation of America, Telefonica (S.A.), Volkswagen AG, Daimler Benz, Vodafone, Proctor \& Gamble, IKEA, Nokia, and Intel were used to provide opportunities to compare disclosure requirements, format differences, and impacts of various accounting standard differences. By comparing and contrasting financial statements of these multi-national enterprises, the students were able to discuss differences between the two sets of accounting and reporting standards. Exhibit 2 is an example of U.S.GAAP and IFRS differences in reporting income statement and balance sheet classifications. 
Exhibit 2: Financial Statement Presentation Under U.S. GAAP and IFRS

\begin{tabular}{|l|l|l|}
\hline & U.S. GAAP & IFRS \\
\hline $\begin{array}{l}\text { Presentation of Expense } \\
\text { Classifications }\end{array}$ & $\begin{array}{l}\text { Categorized by function } \\
\text { (e.g., production, research, } \\
\text { marketing, selling, } \\
\text { administrative }\end{array}$ & $\begin{array}{l}\text { Categorized by either function or } \\
\text { nature (e.g., salaries, rent, } \\
\text { utilities, research, development) }\end{array}$ \\
\hline $\begin{array}{l}\text { Order of items on the } \\
\text { Balance Sheet }\end{array}$ & $\begin{array}{l}\text { Assets } \\
\text { Current } \\
\text { Noncurrent } \\
\text { Liabilities } \\
\text { Current } \\
\text { Noncurrent } \\
\text { Stockholders'Equity }\end{array}$ & $\begin{array}{l}\text { Noncurrent } \\
\text { Current } \\
\text { Shareholders' Equity } \\
\text { Liabilities } \\
\text { Noncurrent } \\
\text { Current }\end{array}$ \\
\hline
\end{tabular}

Source: Fundamentals of Financial Accounting, 3e (2011), Phillips, Libby, and Libby, McGraw-Hill Irwin Publisher (ISBN: 978-0-07-352710-9), Exhibit 5.1, p. 221.

All of the students in the program, except one, had taken at least one financial accounting principles course prior to taking this course. However, except for one student, it had been at least two years (and in most cases, three years) since the financial accounting principles' course had been taken. The aforementioned accounting knowledge deficiency was a major reason for selecting International Accounting and Multinational Enterprises as the textbook for the course. International Accounting and Multinational Enterprises did not require extensive financial accounting knowledge to comprehend and understand the material as presented. The deficiency in the students' financial accounting knowledge required the professor to spend valuable class time and the students to devote time outside of class meetings to reviewing basis accounting principles and standards prior to the discussion of several topics of international accounting.

\subsection{Course Topics}

With most students possessing an inadequate foundation in accounting, a limited number of topics and a lack of depth in the exposure to those topics resulted. The following topics were covered in depth (i.e., sixty-minutes or more were devoted to the topic): causes of international accounting differences, accounting measurements and disclosures, corporate financial disclosure, international accounting standards, international financial reporting standards, standards and global convergence of reporting requirements, and cultural influences on accounting. Between thirty and sixty minutes were devoted to the following topics: accounting development in the global economy, global harmonization of accounting and reporting issues, accounting and financial reporting in emerging capital markets, consolidated financial statements and business combinations. Culture and accounting rules 
development, a subcategory of causes of international accounting differences which looked at the effect of culture on the adoption (or non-adoption) of accounting standards, was clearly the favorite topic of most students. Their international backgrounds and interest in international business most likely contributed to their heighten interest in the effect culture has on emerging accounting ideas.

Other topics briefly covered in the course(i.e., between five and sixty minutes were devoted to the topic) were international financial statement analysis, research and development costs, goodwill and other intangibles, segment reporting, transfer pricing, and budgeting and performance evaluation. Exhibit 3 summarizes the top topics identified in a survey by Zarb and Jagolinzer (2008)of U.S. College and university accounting faculty, whose primary teaching or research interests are in international accounting. Only the responses from instructors who taught at institutions that offered an international accounting course are shown. Of the 49 topics included in the survey, no respondent taught all of them. For example, although inflation and hyperinflation, governance in emerging markets, corporate environmental and social reporting, international risk management, and information systems for multinational planning and control were topics included in the survey, not every instructor reported these topic as being important enough to teach.

With classes meeting three hours each week for 15 weeks, use of the available time was critical. Time (in minutes) spent on a particular topic varied from fifteen minutes (e.g., cultural influences on accounting and international accounting standards) to more than 90 minutes (e.g., causes of international differences, accounting development in the global economy, and corporate financial disclosure). Time coverage for topics covered in the Trilateral MBA program was consistent with the weighted-average times reported in the survey.

Exhibit 3: Top Topics Specified by Academics and Weighted Average Amount of Time in Minutes Spent on Each Topic

\begin{tabular}{|l|l|l|l|l|l|l|}
\hline Topics* & $\begin{array}{l}\text { RGB } \\
\text { Chapter }\end{array}$ & $\begin{array}{l}\text { Weighted } \\
\text { average } \\
\text { minutes }\end{array}$ & $\begin{array}{l}>90 \\
\text { minutes }\end{array}$ & $\begin{array}{l}60-89 \\
\text { minutes }\end{array}$ & $\begin{array}{l}30-59 \\
\text { minutes }\end{array}$ & $\begin{array}{l}<29 \\
\text { minutes }\end{array}$ \\
\hline $\begin{array}{l}\text { Causes of } \\
\text { international } \\
\text { accounting } \\
\text { differences (A) }\end{array}$ & 1,2 & 59 & 25 & 11 & 10 & 13 \\
\hline $\begin{array}{l}\text { Accounting global } \\
\text { development in } \\
\text { the } \\
\text { economy }\end{array}$ & $1,2,7$ & 59 & 20 & 15 & 12 & 12 \\
\hline Accounting & 5,6 & 57 & 20 & 10 & 15 & 12 \\
\hline
\end{tabular}




\begin{tabular}{|c|c|c|c|c|c|c|}
\hline $\begin{array}{l}\text { measurements and } \\
\text { disclosures }\end{array}$ & & & & & & \\
\hline $\begin{array}{l}\text { Corporate } \\
\text { financial } \\
\text { disclosure }\end{array}$ & $3,4,6,8$ & 57 & 7 & 17 & 17 & 16 \\
\hline $\begin{array}{l}\text { Global } \\
\text { harmonization of } \\
\text { accounting and } \\
\text { reporting }\end{array}$ & $3,4,7$ & 59 & 0 & 24 & 16 & 19 \\
\hline $\begin{array}{l}\text { Comparative } \\
\text { international } \\
\text { financial } \\
\text { accounting }\end{array}$ & 3,4 & 56 & 0 & 26 & 10 & 20 \\
\hline $\begin{array}{l}\text { Accounting and } \\
\text { financial reporting } \\
\text { in emerging } \\
\text { capital markets }\end{array}$ & 4 & 57 & 8 & 8 & 17 & 24 \\
\hline $\begin{array}{l}\text { Foreign currency } \\
\text { transactions and } \\
\text { translations } \\
\text { (P) }\end{array}$ & 10,11 & 58 & 0 & 24 & 11 & 23 \\
\hline $\begin{array}{l}\text { Consolidated } \\
\text { financial } \\
\text { statements and } \\
\text { business } \\
\text { combinations }(\mathrm{P})\end{array}$ & 8 & 59 & 7 & 10 & 13 & 29 \\
\hline $\begin{array}{l}\text { Harmonizing } \\
\text { financial reporting } \\
\text { standards }\end{array}$ & 7,16 & 55 & 0 & 19 & 13 & 23 \\
\hline $\begin{array}{l}\text { Fundamentals of } \\
\text { international } \\
\text { accounting } \\
\text { standards }\end{array}$ & $4,5,8$ & 57 & 0 & 17 & 16 & 24 \\
\hline $\begin{array}{l}\text { International } \\
\text { financial } \\
\text { statement analysis }\end{array}$ & 5,6 & 50 & 0 & 16 & 13 & 21 \\
\hline
\end{tabular}




\begin{tabular}{|l|l|l|l|l|l|l|}
\hline $\begin{array}{l}\text { International } \\
\text { accounting } \\
\text { standards }\end{array}$ & $\begin{array}{l}5,8,7,9, \\
10\end{array}$ & 57 & 0 & 23 & 8 & 26 \\
\hline $\begin{array}{l}\text { International } \\
\text { financial reporting } \\
\text { standards }\end{array}$ & $4,9,11$ & 54 & 0 & 16 & 13 & 25 \\
\hline $\begin{array}{l}\text { Cultural } \\
\text { influences on } \\
\text { accounting (A) }\end{array}$ & 2, & 57 & 0 & 16 & 15 & 26 \\
\hline
\end{tabular}

a. Topics are from "What are students taught in international accounting courses?," Bert J. Zarb, Philip Jagolinzer, The CPA Journal (2008), 78:9; Accounting \& Tax Periodicals, 62.

b. A (academics) and $\mathrm{P}$ (practitioners) indicate preferences.

c. $\mathrm{RGB}=$ Radebaugh, Gray, and Black, International Accounting and Multinational Enterprises $\left(6^{\text {th }}\right.$ ed.)

\section{Research Project Paper}

\subsection{Research paper assignment description}

All students were required to prepare a research paper on a topic of their choice. The topic of the paper had to relate either to international accounting or international financial reporting. Each paper had to be an original piece of work, created solely by the student. Requirements of the project paper included the submission of a written proposal addressing the topic to be examined. The proposal had to include a short literature review (i.e., at least five articles) and a list of references. Approval of the proposal was required before the student could begin the research process. The purpose of having an approved proposal was to narrow the research focus. Some students found this requirement to be frustrating because having their initial proposal approved was unusual. When the research process began, students quickly recognized the benefit of constructing a research question with a narrow focus.

Topics covered in the research papers were highly correlated with the nationality of the student writing the paper. Mexican students wrote about Mexican accounting principles and the introduction of IFRS in Mexico, Canadian students wrote about Canadian GAAP and the introduction on IFRS in Canada, and American students wrote about the progress being made in the convergence of IFRS and U.S. GAAP.

\subsection{Benefits of research paper assignment}

The research paper project requirement offered students an opportunity to examine accounting and reporting standards currently existing in their homeland, the complications involved in the adoption of IFRS, the complexity of creating new accounting standards, and 
the influence of current and proposed financial reporting requirements on decision-making. Writing the paper required students to read academic research and practitioner articles that were not on the course reading list and to incorporate the information discussed in these articles into their project paper. Classroom discussions were, also, greatly enhanced by having to read articles not included in the course required reading list. As second-semester graduate students, introduction to scholarly and practitioner articles opened their eyes to the wealth of resources available to them.

The following list is an example of research paper titles. Students expressed positive feedback about the diversity of topics investigated.

What Is the Impact of Changing Accounting Standards to IFRS On the Reporting and Computation of Equity-Based Compensation?

How Will Adopting IFRS Help Developing Countries Like BRIC?

How Will IFRS Affect Cross-Border Investment?

Marketing the Adoption of IFRS

Advantages and Disadvantages of Adopting IFRS in Developing Countries

The Impact of Cultural Dimensions on IFRS's Implementation in Mexico

The Accounting Standard for Business Combinations in China

A Comparison of Old Chinese GAAP, Current Chinese Accounting Standards and IFRS: Changes in Financial Statements

\section{Oral Presentations}

The final requirement for the course was an oral presentation of the completed research paper. The presentation requirement of the course allowed each student to :(1) recognize the importance of being thoroughly familiar with what was happening in their country with respect to IFRS and international accounting; (2) have an opportunity to make a formal oral presentation of his or her research topic in front of their peers; and (3) peer-review two other papers and present their comments as a discussant. Each presentation was limited to one-half hour, which included time for the discussant's comments and a question and answer period. While some apprehension was expected, the professor was pleasantly surprised with the eagerness shown by the students to present their own research.

\section{Student reactions to the course}

\subsection{Comments and preferences}

Student reactions to the course were overwhelmingly positive. They made comments such as "I thought the course (i.e., accounting) would be boring, but (it) really turned out to be very interesting", "I learned more about accounting and financial reporting than I imagined that I would", "This was my first time looking at an actual annual report....and now I can read it", "The information I learned in this class will serve me well, when I go into the real world." One of the graduates of the Trilateral MBA program communicated with the professor that she used parts of her research paper (Marketing IFRS to Industry) in her 
current job to create a marketing plan to promote a new professional certification.

Students indicated a preference for discussing topics in a seminar-style setting, preparing and presenting research papers, and reading both academic and practitioner journal articles in contrast to listening to lectures, reading a textbook, and solving problems, methods that are common to many accounting courses. The smaller class size was thought to be more conducive to class discussions, contribute to a "higher level of learning", and reduce concerns and anxieties about inadequate oral communication skills. Students also preferred the research paper project and the accompanying oral presentations as compared to completion of typical classroom examinations. However, quizzes were given periodically during the semester to encourage students to read the textbook and assigned articles, as well as to prepare for classroom discussions.

\subsection{Benefits Identified by Students}

Students identified the following benefits of the program:

- Small class size, which allowed for vibrant discussions in a doctoral seminar-type setting.

- Synergistic learning, which resulted from one-on-one discussions with professors and peers.

- Introduction to a topic that is not normally covered in other MBA programs.

- An opportunity to study the impact of culture on emerging ideas and thought.

- Cultural diversity of cohort, educational institutions involved, and countries visited.

\section{Suggestions to strengthen the course}

\subsection{Course textbook}

Not having an MBA level international accounting text book with a copyright date after 2010 that is written with the needs and accounting knowledge of non-accounting majors in mind forced the professor to depend heavily on both academic and practitioner articles. However, International Accounting and Multinational Enterprises was an acceptable choice for the course, as it provided adequate explanations, references, and end of chapter discussion material (questions, exercises, and cases). The selected reference lists at the end of each chapter proved to be an indispensable resource for the professor and students.

\subsection{Close collaboration of international accounting and international finance faculty}

Because the Trilateral MBA students take the international accounting and finance courses concurrently, the U.S. GAAP and IFRS concepts studied in the accounting course are timely complements to the material covered in the international finance course. Financial statement analysis, transparency and disclosure, and foreign currency transactions and translation are just a few of the topics that are applicable to each course. Having common topics allow members of the two faculties the opportunity to collaborate on issues concerning the degree of difficulty and the timing/sequence of presentation of the material that is considered to be 
most beneficial to the students.

\subsection{Financial accounting as a prerequisite}

Completing a financial accounting principles course within one year of taking this course would better prepare students for a more in-depth study of technical international accounting topics, such as international transfer pricing, foreign currency transactions and translations, business combination and consolidated financial statements of multinational corporations, specific international accounting standards, and international segment reporting. The most desirable option would be to have a graduate level financial accounting principle course as a prerequisite.

\subsection{Faculty training time}

Adequate training for faculty is essential to creating, developing, and teaching a successful course. Large public accounting firms and professional organizations have produced a wealth of IFRS materials, which are available through their corporate websites and webinars. Continuing professional education (CPE) sessions are available through various professional accounting associations (e.g., American Accounting Association, American Institute of Certified Public Accountants, Association of Chartered Certified Accountants; Financial Accounting Standards Board, Institute of Management Accountants, International Accounting Standards Board, International Organization of Securities Commissions) as well as commercial CPE providers. Online webinars produced by textbook publishers and the Big 4 accounting firms are readily available. [The AICPA awards a certificate for the completion of a comprehensive, integrated curriculum of 25 online, self-study courses.] In addition to self-study opportunities, it may be necessary to grant a one or two course release to allow the faculty member time to become adequately versed in current international accounting issues.

\subsection{Ethics}

Including an ethics component would strengthen the course by exposing the students to a variety of ethical dilemmas. Possible ethical case studies could include recent events involving Walmart, Enron, WorldCom, and Facebook. An article by Curtis C. Verschoor titled IFRS Would Escalate Ethical Challenges for Accountants (2010) points out that switching from a rules-based (U.S. GAAP) to a principles-based (IFRS) system of accounting will likely create ethical challenges requiring accountants to utilize greater professional judgment.

\section{Closing remarks and implications}

An increase in international trade, international financial commerce, and the opportunity to do business in emerging global economies require a basic understanding of international financial reporting standards in order be an effective decision maker. As more countries adopt IFRS, multinational organizations will need to increase the number of professionals who understand how the data they use is prepared, and how to properly use it to make rational and supportable business decisions.

Research by Bates et al. (2011) found, to their surprise, that there was a lack of international accounting course offerings by the top accounting undergraduate, graduate, and doctoral 
programs (see Appendix B for a list of top accounting programs that offer international accounting courses). They conjectured the following reasons for the dearth of international accounting courses:1) international accounting and reporting issues are already being covered in existing intermediate and advanced accounting courses; and 2) the subject is not perceived by faculty as a topic deserving of a stand-alone course because the SEC, FASB, and other [US] professional accounting organizations have not definitively decided to move to IFRS. Regardless of the reason, there remains little support for the inclusion of a stand-alone course covering international accounting issues in the accounting curriculum. Were it not for the requirement that the professor's school participate in a program that required a stand-alone international accounting course, one has to wonder whether or not it would have been offered.

This course serves as an opportunity to address accounting faculty concerns regarding the importance of integrating international accounting topics into the curricula. Evidence was obtained that once exposed to international accounting, students develop an interest in and take a liking to the subject. Elective courses in international economics, marketing, finance, and business are common in both undergraduate and master's programs. In an article written by Jason Cherubini, Kevin Rich, Hong Zhu, and Alfred Michenzi titled IFRS in the General Business Curriculum: Why Should We Care? (2011), the authors give the following reasons for integrating IFRS into the business school curriculum:

- Individuals well versed in IFRS are more ready to engage in the global economy.

- Obtaining an understanding of alternative accounting standards can help students gain a better understanding of U.S.GAAP and the changing nature of accounting rules.

- By exposing students to a second set of accounting standards such as IFRS, a new graduate of any (academic) major is be more likely to understand the changing nature of accounting and be more capable of utilizing critical thinking skills in their application of accounting concepts.

- IFRS offers a unique opportunity to educate future investors.

Perhaps introducing international accounting to MBA students and then obtaining feedback on the perceived impact that the course has made on their careers will lead to a more serious review of the benefit to be gained by its inclusion in both undergraduate and graduate MBA programs.

A major implication of this paper is the ease with which an international accounting course can be introduced into an MBA program. There are sufficient resources available through the big 4 accounting firms (PricewaterhouseCoopers, Deloitte Touche Tohmatsu, Ernst \& Young, and KPMG), major professional accounting organizations (AICPA, IIA, IMA), and international organizations promulgating the adoption of international financial reporting standards (IASB) with the exception of a textbook geared toward non-accounting students. Trained faculty is an obstacle that can be overcome with proper education and time-release allowed to faculty to obtain it. 


\section{1l Macrothink}

International Journal of Accounting and Financial Reporting

ISSN 2162-3082 2012, Vol. 2, No. 1

Although differences exist between U.S. and non-U.S. schools in the perceived importance of some international accounting topics, officials from these schools view the lack of emphasis on international accounting in master's and doctoral programs as a major barrier to its incorporation into the undergraduate and graduate curricula. As part of this course's purpose, coverage of international accounting issues provided both an exposure to topics, which have traditionally not been available, as well as, an enrichment of the educational experience of the students and faculty, who participated. The course offering also fulfilled the school's responsibility and added value to the Trilateral MBA program by enhancing the ability of students to understand, analyze, interpret, and use financial information prepared following international accounting and international financial reporting standards to make business decisions.

\section{References}

Ashcroft, P., G. C., and Smith, L.M. Smith.(2008). Faculty perspectives on international accounting topics. Advances in Accounting, 24, 139-144.

Bates, H. L., Waldrup, B. E., \& Shea, V.(2011).The effect of international financial reporting standards convergence on U.S. accounting curriculum.American Journal of Business Education, 4(7), 39-42.

Cherubini, J., Rich, K., Zhu, H, \&Michenzi, A. (2011). IFRS in the general business curriculum: Why should we care? The CPA Journal, 81(2), 13-15.

Radebaugh, L. H., Gray, S. J., \& Black, E. L. (2006).International Accounting and Multinational Enterprises, ( $6^{\text {th }}$ ed.)Hoboken, NJ:John Wiley \& Sons.

Securities and Exchange Commission.(2010). Commission Statement in Support of Convergence and Global Accounting Standards.SEC Release Nos. 33-9109, 34-61578. Author.

Securities and Exchange Commission. (2011). Work Plan for the Consideration of Incorporating International Financial Reporting Standards into the Financial Reporting System of U.S. Issuers; An Analysis of IFRS in Practice - A Securities and Exchange Commission Staff Paper (November 16, 2011).Division of Corporate Finance Office of the Chief Accountant United States Securities and Exchange Commission. Author.

Verschoor, C. C. (2010). IFRS would escalate ethical challenges for accountants. Strategic Finance.92(1), 13-14, 18.

Zarb, B. J., \& Jagolinzer, P. (2008). What are students taught in international accounting courses? The CPA Journal, 78(9), 60-65. 


\section{Macrothink}

International Journal of Accounting and Financial Reporting ISSN 2162-3082 2012, Vol. 2, No. 1

\section{Appendix}

Appendix 1. Special Topics: International Accounting Course Reading List

Required textbook and support material:

Radebaugh, L. H., Gray, S. J., \& Black, E. L. (2006).International Accounting and Multinational Enterprises, $\left(6^{\text {th }}\right.$ ed.)Hoboken, NJ: John Wiley \& Sons.

Deloitte. (2008). Deloitte: IFRSs and U.S. GAAP: A pocket comparison (An IAS Plus guide).

Durkee, D. (2006). International accounting for business majors. The Accounting Educators' Journal, 16, 82-96.

KPMG. (2009). IFRS Compared to U.S. GAAP: An Overview.

Available on call in the library:

Choi, F. D. S., \& Meek, G. K. (2008).International Accounting. (6 ${ }^{\text {th }}$ ed.).Upper Saddle River, NJ: Pearson Prentice Hall.

Doupnik, T., \& Perera, H. (2009).International Accounting. (2 $2^{\text {nd }}$ ed.). New York, NY: McGraw-Hill Irwin.

Saudagaran, S. M. (2009).International Accounting: A User Perspective. ( $3^{\text {rd }}$ ed.). New York, NY: Thomson South-Western.

Chapter 1 Accounting and Business Financial Statement Analysis

Carmona, S., \&Trombetta, M. (2008).On the global acceptance of IAS/IFRS accounting standards: The logic and implications of the principles-based system. Journal of Accounting and Public Policy, 27(6),455-461.

Heffes, E.M., \&Graziano, C. M.(2007). Accounting without borders: Has its time come? Financial Executive, 23(7), 22-26.

Langmead, J. M., Phillips-Wren, G., Soroosh, J., Zhu, H., Kelly, K. A., \& Thomas, K. S. (2011).How to adopt IFRS in five steps. Strategic Finance, 93(3), 53-60.

Nobes, C. (1998). Towards a general model of the reasons for international differences in financial reporting. Abacus, 34(2), 162-186.

\section{Chapter 2 International Accounting Patterns, Culture and Development}

Choi, D. S., \&Levich, R. M. (1991).Behavioral effects of international accounting diversity. Accounting Horizons, 5(2), 1-13.

Gray, S. J. (1988). Towards a theory of cultural influence on the development of accounting systems internationally. Abacus, 24(1), 1-15.

Tsakumis, G.T., Campbell, D. R., \& Doupnik, T. (2009).IFRS: Beyond the standards. Journal of Accountancy, 207(2), 34-39.

Tsakumis, G. T. (2007). The influence of culture on accountants' application of financial reporting rules. Abacus, 43(1), 27-48. 


\section{Macrothink \\ International Journal of Accounting and Financial Reporting \\ ISSN 2162-3082 \\ 2012, Vol. 2, No. 1}

Chapter 3 Comparative International Financial Accounting

Black, E.L. and White, J. J. (2003).An international comparison of income statement and balance sheet information: Germany, Japan, and the US. European Accounting Review, 12(1), $29-46$.

Larson, R. K., \& Street, D.L. (2006). The roadmap to global accounting convergence. The CPA Journal, 76 (10), 36-43.

Pounder, B. (2008).The future of private-company financial reporting. Strategic Finance, 90(2), 59-61.

Pounder, B. (2008).Myths and facts about convergence. Strategic Finance, 90(3), 59-60.

Chapter 5 International Financial Statement Analysis

Choi, F.D. S., Hino, H., Min, S.K., Nam, S.O., Ujiie, J., \&Stonehill, A.I.. (1983). Analyzing foreign financial statements: The use of international ratio analysis. Journal of International Business Studies, 14(01), 113-131.

McClain, G., \&McLelland, A.J. (2008). Shaking up financial statement presentation: An early look at the FASB and IASB financial statement project. Journal of Accountancy, 206(5), 56-64.

\section{Chapter 6 International Transparency and Disclosure}

Barth, M.E. and Schipper, K. (2008).Financial reporting transparency. Journal of Accounting, Auditing, \& Finance,23(2), 173-190.

Gupta, P.P., Linthicum, C., \& Noland, T.G. (2007).The road to IFRS. Strategic Finance, 89(3), 29-33.

Ostling, D. (2009). Converting to IFRS. Journal of Accountancy, 207(2), 28.

Jeanjean, T. \&Stolowy, H. (2008). Do accounting standards matter? An exploratory analysis of earnings management before and after IFRS adoption. Journal of Accounting and Public Policy, 27(6), 480-494.

Kumar, K. (2008). Corporate voluntary disclosure: Empirical evidence from Italy and the United States. The Journal of Global Business Issues-Conference Edition, Spring, 49-50.

Chapter 7 Standards and Global Convergence

Anonymous. (2008). The Standard-Bearer: (AcSEC) Chairman examines AcSEC's changing role and the progress of international convergence. Journal of Accountancy, 206(2), 62-65.

Baker, R. (2008). The inevitable move to IFR? The CPA Journal, 78(12), 6-9.

Blanchette, M. (2007).IFRS in Canada: Evolution or revolution? CMA Management, 81(3), 22-26.

Tokar, M. (2005).Convergence and the implementation of a single set global standards: The real-life challenge. Northwestern Journal of International Law \& Business, 25(3), 687-710. 


\section{Macrothink \\ International Journal of Accounting and Financial Reporting \\ ISSN 2162-3082 2012, Vol. 2, No. 1}

Chapter 8 International Business Combinations, Goodwill, and Intangibles

Anonymous. (2009). The role of mark-to-market accounting in the financial crisis. The CPA Journal, 79(1), 20-24.

Deane, J. T., \& Heilman, S.H. (2009).Using IFRS to drive business development opportunities for small and midsize firms. Journal of Accountancy, 207(2), 34-39.

King, A.M. (2009a). Determining fair value. Strategic Finance, 9(7), 27-32.

King, A.M. (2009b). Fair value is dangerous for cost management. Cost Management, 23(1), 41-47.

Daniels, L. A. (2010). Fair value changes ahead. The CPA Journal, 80(1), 24-27.

Chapter 12 Corporate Governance and Control of Global Operations

Peng, S., Tondkar, R.H., Smith, J.L., \&Harless, D.W. (2008).Does convergence of accounting standards lead to the convergence of accounting practices? A study from China. The International Journal of Accounting, 43(4), 448-468. 
Appendix 2.International Accounting Course Offerings At Top Accounting Programs (Master's Programs)

\begin{tabular}{|c|c|}
\hline \multicolumn{2}{|l|}{ Master's Programs } \\
\hline \multicolumn{2}{|l|}{ Required Courses: } \\
\hline Michigan State University & $\begin{array}{l}\text { Management in Global Enterprises ( } 3 \text { credit } \\
\text { hours) }\end{array}$ \\
\hline Texas A\&M University & International Accounting ( 3 credit hours) \\
\hline \multicolumn{2}{|l|}{ Elective Courses: } \\
\hline Brigham Young University & $\begin{array}{l}\text { International Accounting and Multinational } \\
\text { Enterprises ( } 3 \text { credit hours) }\end{array}$ \\
\hline University of Florida & International Accounting Issues ( 2 credit hours) \\
\hline University of Georgia & International Accounting (1.5 hours) \\
\hline University of Illinois & $\begin{array}{l}\text { Multinational Enterprise Accounting ( } 4 \text { credit } \\
\text { hours) }\end{array}$ \\
\hline Michigan State University & $\begin{array}{l}\text { Management Accounting in Global Enterprises } \\
\text { ( } 3 \text { credit hours) }\end{array}$ \\
\hline University of Mississippi & International Accounting ( 3 credit hours) \\
\hline $\begin{array}{l}\text { University of North Carolina at } \\
\text { Chapel Hill }\end{array}$ & Global Immersion ( 3 credit hours) \\
\hline Notre Dame University & $\begin{array}{l}\text { International Financial Reporting Standards ( } 2 \\
\text { credit hours) }\end{array}$ \\
\hline University of Southern California & $\begin{array}{l}\text { Accounting for the Global Business } \\
\text { Environment ( } 3 \text { credit hours) }\end{array}$ \\
\hline \multirow[t]{2}{*}{ University of Texas - Austin } & $\begin{array}{l}\text { International Accounting Policies and } \\
\text { Procedures (Variable credit hours) }\end{array}$ \\
\hline & $\begin{array}{l}\text { International and European Accounting } \\
\text { Standards (Variable credit hours) }\end{array}$ \\
\hline University of Washington & $\begin{array}{l}\text { Issues in International Accounting ( } 4 \text { credit } \\
\text { hours) }\end{array}$ \\
\hline
\end{tabular}




\begin{tabular}{|c|c|}
\hline & $\begin{array}{l}\text { Business and International Taxation ( } 4 \text { credit } \\
\text { hours) }\end{array}$ \\
\hline \multicolumn{2}{|c|}{ Doctoral Programs } \\
\hline None & \\
\hline
\end{tabular}

Source: Bates, H. L., Waldrup, B. E., \& Shea, V. (2011).The effect of international financial reporting standards convergence on U.S. accounting curriculum, American Journal of Business Education.4(7), 41.

\section{Copyright Disclaimer}

Copyright reserved by the authors.

This article is an open-access article distributed under the terms and conditions of the Creative Commons Attribution license (http://creativecommons.org/licenses/by/3.0/). 